\title{
Survey of programmatic experiences and challenges in delivery of hepatitis $B$ and $C$ testing in low- and middle-income countries
}

Azumi Ishizaki ${ }^{1}$, Julie Bouscaillou², Niklas Luhmann², Stephanie Liu ${ }^{3}$, Raissa Chua ${ }^{3}$, Nick Walsh³, Sarah Hess ${ }^{1}$, Elena Ivanova ${ }^{4}$, Teri Roberts ${ }^{4}$ and Philippa Easterbrook ${ }^{1 *}$

\begin{abstract}
Background: There have been few reports on programmatic experience of viral hepatitis testing and treatment in resource-limited settings. To inform the development of the 2017 World Health Organization (WHO) viral hepatitis testing guidance and in particular the feasibility of proposed recommendations, we undertook a survey across a range of organisations engaged with hepatitis testing in low- and middle-income countries (LMICs). Our objective was to describe current hepatitis $B$ and $C$ testing practices across a range of settings in different countries, as well as key barriers or challenges encountered and proposed solutions to promote testing scale-up.

Methods: Hepatitis testing programmes in predominantly LMICs were identified from the WHO Global Hepatitis Programme contacts database and through WHO regional offices, and invited to participate. The survey comprised a six-part structured questionnaire: general programme information, description of hepatitis testing, treatment and care services, budget and funding, data on programme outcomes, and perceptions on key barriers encountered and strategies to address these.

Results: We interviewed 22 viral hepatitis testing programmes from 19 different countries. Nine were from the African region; 6 from the Western Pacific; 4 from South-East Asia; and 3 from Eastern Europe. All but four of the programmes were based in LMICs, and 10 (45.5\%) were supported by non-governmental or international organizations. All but two programmes undertook targeted testing of specific affected populations such as people living with HIV, people who inject drugs, sex workers, health care workers, and pregnant women. Only two programmes focussed on routine testing in the general population. The majority of programmes were testing in hospital-based or other health facilities, particularly HIV clinics, and community-based testing was limited. Nucleic acid testing (NAT) for confirmation of HCV and HBV viraemia was available in only $30 \%$ and $18 \%$ of programmes, respectively. Around a third of programmes required some patient co-payment for diagnosis. The most commonly identified challenges in scale-up of hepatitis testing were: limited community awareness about viral hepatitis; lack of facilities or services for hepatitis testing; no access to low cost treatment, particularly for HCV; absence of national guidance and policies; no dedicated budget for hepatitis; and lack of trained health care and laboratory workers.

(Continued on next page)
\end{abstract}

\footnotetext{
* Correspondence: easterbrookp@who.int

${ }^{1}$ Global Hepatitis Programme, World Health Organization, 20 Avenue Appia,

1211, 27 Geneva, Switzerland

Full list of author information is available at the end of the article
} 
(Continued from previous page)

Conclusions: At this early stage in the global scale-up of testing for viral hepatitis, there is a wide variation in testing practices and approaches across different programmes. There remains limited access to NAT to confirm viraemia, and patient self-payment for testing and treatment is common. There was consensus from implementing organizations that scale-up of testing will require increased community awareness, health care worker training, development of national strategies and guidelines, and improved access to low cost NAT virological testing.

Keywords: Hepatitis testing, WHO guidelines on hepatitis B and C testing, Programme experience, Feasibility, Low- and middle-income countries

\section{Background}

Hepatitis B virus (HBV) and C (HCV) infections are major causes of chronic liver disease and associated morbidity due to cirrhosis and hepatocellular carcinoma (HCC) globally and together accounted for an estimated 1.34 million deaths in 2015 [1]. The disease burden of chronic HCV and $\mathrm{HBV}$ infection is disproportionately high in low- and middle-income countries (LMICs), especially in East and South East Asia and in Sub-Saharan Africa for HBV infection [2]. However, despite the high prevalence of disease, and the availability of effective curative treatment for $\mathrm{HCV}$ infection using the new direct acting anti-viral (DAA) drugs, as well as long-term suppressive antiviral treatment for $\mathrm{HBV}$, most people infected with $\mathrm{HBV}$ or $\mathrm{HCV}$ globally have never been tested and so remain unaware of their infection. Key reasons for this current very low rate of hepatitis testing in LMICs include: limited laboratory capacity and access to reliable, low-cost, HCV diagnostics, and lack of testing guidance specifically for LMICs [3].

WHO has recently developed guidelines on testing for hepatitis B and C infection that are intended as the basis for development of national guidelines for hepatitis testing in resource-limited settings [4]. Formulation of the recommendations was based on the GRADE approach (Grading of Recommendations, Assessment, Development and Evaluation) that include an assessment of the quality of evidence, but also considerations of patient and healthcare worker acceptability and preferences, resource use and feasibility $[5,6]$. At present, although there are more than 40 published reports of different viral hepatitis testing programmes [7-55], the majority of these $(88 \%)$ were from high-income countries, mainly the United States and Western Europe. In LMICs, there have been only two reports from Sub-Saharan Africa $[27,31]$, three from Asia $[44,49,52]$ and one from Latin America [46]. We therefore undertook a survey of programmatic experience with testing for hepatitis $\mathrm{B}$ and $\mathrm{C}$ across a range of settings in LMICs, where access to laboratory infrastructure and specialised tests is limited. Our objective was to inform feasibility of potential recommendations on testing approaches (who and where to test) and how to test (selection of assays) in the WHO viral hepatitis testing guidelines, and also to assess key perceived barriers/challenges and strategies to address these and so guide implementation of hepatitis testing and treatment services.

\section{Methods}

\section{Survey sites}

Potential hepatitis testing and treatment programme sites in LMICs were identified from the various contacts databases of the WHO Global Hepatitis Programme (GHP) and of key WHO implementing partners [Médecins du Monde (MdM), Médecins sans Frontières (MsF) and Forum for Collaborative Research]. Twenty-two programmes from Asia, Sub-Saharan Africa and Eastern Europe that were broadly representative of different types of testing programmes ie. governmental or nongovernmental organisations; hospital or community based testing; general or specific target populations; and from different geographic regions, were invited to participate in the survey.

\section{Survey questionnaire}

A 33 question semi-structured questionnaire was developed by WHO and MdM, which was organized into five sections: PART A: Demographics of interviewees (professional profile, working experience); PART B: Programme information (Who is tested and where; what assays/algorithms are used; counselling and training; funding and costs of testing and treatment); PART C: Existence of protocol for viral hepatitis care and treatment; PART D: Perceived barriers/challenges and solutions; PART E: Provision of relevant epidemiological data. PARTS A to C comprised multiple choice standardized questions, with text fields to allow for additional comments, while PART D involved open-ended questions (Additional file 1). Interviews were conducted by telephone or in person by 7 persons (AI, NL, JB, SL, RC, NW, SH, PE) between June to September 2015, and immediately transcribed and sent to participants to ensure accuracy.

\section{Survey analysis}

Questionnaire responses of PARTS A to C were analysed using descriptive statistics within Microsoft Excel. The written responses to PART D were analysed using a 
thematic analysis approach [56]. A systematic reading and coding of the transcripts allowed us to identify major themes and categories of perceived barriers and solutions for scale-up of testing, and six major categories were identified through consensus discussion within the study team.

\section{Results}

\section{General characteristics}

Overall, we evaluated 22 programmes from 19 countries [9 from the African region: Chad, Côte d'Ivoire, Democratic Republic of the Congo, Gambia, Kenya, Niger, Tanzania, Togo and Uganda]; 6 in Western Pacific: [Fiji, Hong Kong SAR/China, Mongolia, Philippines and Viet Nam (two programmes)]; 4 in South-East Asia: [India, Myanmar (two programmes) and Thailand]; and 3 in Eastern Europe: [Georgia and Ukraine (two programmes)]. All but four of the programmes were based in LMICs according to World Bank classification in 2015 [57]. Seven countries (36.8\%) were classified as low-income countries (Chad, Democratic Republic of the Congo, Gambia, Niger, Tanzania, Togo and Uganda); eight $(42.1 \%)$ as lower-middle income countries (Côte d'Ivoire, India, Kenya, Mongolia, Myanmar, Philippines, Ukraine and Viet Nam), and four (21.1\%) as uppermiddle or high-income countries (Fiji, Georgia, Hong Kong SAR/China and Thailand) (Table 1). The majority of these countries $(12,54.5 \%)$ had a high HBsAg prevalence in the general population and the main route of transmission was mother to child. In contrast, only four countries had a high HCV prevalence in the general population largely as a result of transmission through poor injection practices in the past, with an additional 6 countries with high prevalence in specific key populations such as people who inject drugs (PWID). The majority of the nine African countries had low prevalence (Table 2) [58-70]. Figure 1 shows the geographic distribution of these programmes annotated with key features (category of programme, level of coverage, number of sites, duration of programme, target population for testing, testing setting, type of test used, and availability of funding for testing and treatment).

Of the 22 programmes included in the analysis, 10 (45.5\%) were implemented by non-governmental or international organizations (NGO/IO), namely MdM, MSF, Alliance Ukraine, and Expertise France; 3 (13.6\%) through national governments; 6 (27.3\%) by hospitals, and 3 by independent research institutions (13.6\%). More than half of the programmes had been implemented for more than 2 years, and in $40.9 \%$ for longer than 5 years. Twelve of the programmes $(54.5 \%)$ were implemented at just a single site, while $3(13.6 \%)$ had a regional coverage, and 7 (31.8\%) were being implemented nationally. Twenty programmes (90.9\%) offered both HCV and HBV testing and two
Table 1 Characteristics of 22 viral hepatitis testing programmes

\begin{tabular}{ll}
\hline Programme characteristics & $\begin{array}{l}\text { Total, } n \\
(\%)\end{array}$ \\
\hline Geographic location of testing programmes & \\
Africa & $9(40.9)$ \\
Europe & $3(13.6)$ \\
South-East Asia & $4(18.2)$ \\
Western Pacific & $6(27.3)$
\end{tabular}

Income categories of countries where programmes conducted

$n=19$ countries

Low-income

$7 / 19(36.8)$

Lower-middle income

$8 / 19(42.1)$

Upper-middle

3/19 (15.8)

High-income

$1 / 19(5.3)$

Programme coverage

National

Regional

3 (13.6)

Local

$12(54.5)$

Number of testing sites

More than five

Two to five

6 (27.3)

One

8 (36.4)

Not indicated

$1(4.5)$

Type of organisation leading programme

Non-governmental or international organization $10(45.5)$

Government

Hospital

Research institution

$3(13.6)$

Duration of programme

$\geq 5$ years

2 to 4 years

$\leq 1$ year

$4(18.2)$

No response

$5(22.7)$

Target population and location of testing

Target population for testing

Specific target populations only $11(50)$

General population ${ }^{\mathrm{b}}$ only 2 (9.1)

General and specific target populations 9 (40.9)

Details of specific target population (multiple options possible)

HIV positive 11 (50)

PWID

$10(45.5)$

Clinical suspicion of hepatitis (Abnormal liver

6 (27.3)

function tests or symptoms/signs)

Sex worker

$6(27.3)$

Pregnant women

$6(27.3)$

Health care worker

$6(27.3)$

Prisoner 
Table 1 Characteristics of 22 viral hepatitis testing programmes (Continued)

\begin{tabular}{ll}
\hline Programme characteristics & $\begin{array}{l}\text { Total, } n=22 \\
(\%)\end{array}$ \\
\hline Family of HBV/HCV/HIV positive & $3(13.6)$ \\
Children of positive mothers & $3(13.6)$ \\
MSM & $3(13.6)$ \\
Other $^{c}$ & $5(22.7)$
\end{tabular}

Testing setting (multiple options possible)

$\begin{array}{ll}\text { Hospital-based } & 12(54.5) \\ \text { HIV clinic } & 10(45.5) \\ \text { Harm reduction service } & 6(27.3) \\ \text { Primary health care facility } & 4(18.2) \\ \text { Outreach programme } & 4(18.2) \\ \text { Antenatal clinic } & 4(18.2) \\ \text { Private sector } & 2(9.1) \\ \text { Community }_{\text {Other }^{d}} & 1(4.5) \\ \end{array}$

\section{Approaches to testing}

Who initiates testing? (multiple options possible)

Provider

\section{Client}

Not indicated

Who delivers testing? (multiple options possible)

$$
\text { Physician }
$$

Laboratory technician

Counsellor

Nurse

Other health care worker

$4(18.2)$

Other $^{\mathrm{e}}$

Testing approach for HCV (20 programmes) ${ }^{f}$

RDT standalone

EIA standalone

RDT/EIA + NAT

NAT standalone

Not indicated

Testing approach for HBV (22 programmes) ${ }^{9}$

$\begin{array}{ll}\text { RDT standalone } & 11(50) \\ \text { EIA standalone } & 6(27.3) \\ \text { RDT/EIA + NAT } & 4(18.2) \\ \text { Not indicated } & 1(4.5) \\ \text { ntegrated testing (multiple options possible) } & \end{array}$

With HIV

With HIV/HBV/HCV/Syphilis

With HBV/HCV

With HIV/HBV/HCV/TB
Table 1 Characteristics of 22 viral hepatitis testing programmes (Continued)

\begin{tabular}{|c|c|}
\hline Programme characteristics & $\begin{array}{l}\text { Total, } n=22 \\
(\%)\end{array}$ \\
\hline \multicolumn{2}{|l|}{ Liver staging in those with positive test } \\
\hline Not routinely done & $6(27.3)$ \\
\hline Yes $^{\text {h }}$ & $16(72.7)$ \\
\hline \multicolumn{2}{|l|}{ Counseling } \\
\hline Pre-/post- counseling & $15(68.2)$ \\
\hline No counseling/or unknown & $7(31.8)$ \\
\hline \multicolumn{2}{|l|}{ Access to treatment and funding } \\
\hline \multicolumn{2}{|l|}{ Treatment availability } \\
\hline $\mathrm{HBV}^{\mathrm{i}}$ & $18(81.8)$ \\
\hline $\mathrm{HCV}$ & $14(70, n=20)$ \\
\hline No treatment for either HBV and HCV & $2(10, n=20)$ \\
\hline \multicolumn{2}{|l|}{$\begin{array}{l}\text { Funding source for HCV testing (multiple options } \\
\text { possible, } 20 \text { programmes) }\end{array}$} \\
\hline Support from NGO/IO/Government/Other donor & $15(75)$ \\
\hline Patient self-payment & $7(35)$ \\
\hline Private insurance & $4(20)$ \\
\hline
\end{tabular}

Funding source for HBV testing (multiple options possible, 22 programmes)

Support from NGO/IO/Government/Other donor 19 (86.4)

Patient self-payment 8 (36.4)

Private insurance 4 (18.2)

Financial support for treatment

For HBV $6(27.3)$

For HCV

$7(35, n=20)$

PWID people who inject drug, MSM men who have sex with men, RDT rapid diagnosed testing, EIA enzyme immunoassay, NAT nucleic acid testing, HIV human immunodeficiency virus, $H B V$ hepatitis $B$ virus, $H C V$ hepatitis $C$ virus, $T B$ tuberculosis

aBased on the World Bank classification in 2015 [57]; b General population included general population and blood donor; 'Other included non-injecting drug users, migrants, military and TB positive persons; ${ }^{\mathrm{d} O t h e r}$ included two prisons, one HIV/TB clinic and one sexually transmitted infection clinic; ${ }^{\mathrm{e} O t h e r}$ included self-testing; ${ }^{\mathrm{R} D T} / \mathrm{EIA}+\mathrm{NAT}(n=3)$ as an optional approach; ${ }^{9} \mathrm{RDT} /$ EIA + NAT $(n=2)$ as an optional approach to evaluate the treatment eligibility. One programme offered RDT standalone for blood donor screening;

${ }^{h}$ Fibroscan available $(n=9)$ and APRI score $(n=7)$; 'HBV treatment only available for HBV-HIV co-infected persons and not for HBV mono-infected persons $(n=9)$

programmes in Gambia and Togo (9.1\%) only offered testing services for HBV infection.

The majority (63.6\%) of the 22 interviewees were medical doctors. Five $(22.7 \%)$ of medical doctors worked as physicians within the programmes, $5(22.7 \%)$ as programme managers and $4(18.2 \%)$ as policy makers and implementers. The remaining 8 were non-medical workers of which 7 worked as programme coordinators. All interviewees had at least 3 years experience in the field and 5 (22.7\%) had more than 10 years experience. 
Table 2 Epidemic profiles of hepatitis B and C infection in the countries covered by the survey

\begin{tabular}{ll}
\hline HBV epidemiology & Country number (\%) and name \\
High seroprevalence $(>5 \%)$ in & $12(54.5 \%)$ \\
general population & Gambia, Thailand, Chad, Mongolia, \\
& Côte d'Ivoire, Vietnam, Niger, \\
& Uganda, Hong Kong SAR/China, \\
& Democratic Republic of the Congo, \\
& Tanzania, Kenya \\
& $3(13.6 \%)$ \\
Intermediate seroprevalence & Fiji, Philippines, Myanmar \\
$(3-5 \%)$ in general population & $3(13.6 \%)$ \\
Low seroprevalence $(<3 \%)$ in & Ukraine, India, Georgia \\
general population &
\end{tabular}

HCV epidemiology based on anti-HCV antibody

High seroprevalence $(>3 \%)$ in general population and concentrated epidemic among PWID

Intermediate/low seroprevalence (1-3\%) in general population but concentrated epidemic among PWID

Low seroprevalence $(<1 \%)$ in general population

\section{Country number (\%) and name}

$3(13.6 \%)$

Georgia, Mongolia, Ukraine

\section{$5(22.7 \%)$}

India, Philippines, Thailand, Myanmar, Vietnam

$9(40.9 \%)$

Chad, Côte d'Ivoire, Democratic Republic of the Congo, Gambia, Hong Kong SAR/China, Kenya, Niger, Tanzania, Uganda

Source: [58-70]; the HCV prevalence data provided by the respondents are presented for Côte d'Ivoire, Mongolia, Niger, Philippines, Togo and Uganda as no published data is available from these countries

Overall, $94.7 \%$ of programmes were based in LMICs of which 7 countries (36.8\%) were classified as low-income countries according to World Bank classification in 2015 [57] (Chad, Democratic Republic of the Congo, Gambia, Niger, Tanzania, Togo and Uganda). Eight countries (42.1\%) were lower-middle income countries (Côte d'Ivoire, India, Kenya, Mongolia, Myanmar, Philippines, Ukraine and Viet Nam), and 4 (21.1\%) were uppermiddle and above income countries (Fiji, Georgia, Hong Kong SAR/China and Thailand).

\section{Setting and target population}

The majority of programmes indicated that they offered hepatitis testing in hospital-based settings (54.5\% of programmes), but specifically also in human immunodeficiency virus (HIV) clinics (45.5\%), harm reduction services $(27.3 \%)$, primary health care facilities $(18.2 \%)$, and antenatal clinics (18.2\%). Only four programmes (18.2\%) undertook outreach (Georgia, Kenya, Tanzania and Ukraine) or only one (4.5\%) undertook communitybased testing (Gambia). All but two of the programmes included targeted testing of specific affected populations, especially people living with HIV $(11,50 \%)$ and PWID $(10,45.5 \%)$. There were only two programmes that were exclusively dedicated to general population testing (9.1\%) (Côte d'Ivoire and Gambia). All NGO/IO supported programmes focussed on testing of key and marginalised populations and only one government programme (Chad) supported a general population testing approach (4.5\%). The testing settings and target populations are described in Table 1 and Fig. 1.

\section{Diagnostic assays and testing algorithm}

Most of the programmes (16, 77.3\%) offered some form of integrated testing - combining HBV and HCV testing (11 of 17 programmes, 64.7\%) or with HIV (15 of 17 programmes, $88.2 \%$ ). The majority of hepatitis testing was provider-initiated by doctors, but in 8 (36.4\%) programmes testing was initiated by the client (Chad, Côte d'Ivoire, Fiji, Georgia, Kenya, Myanmar, Togo and Ukraine). Very few programmes made use of community or peer workers.

Rapid diagnostic tests (RDT) alone were used respectively in $10(50 \%)$ of the 20 programmes offering HCV testing, and 11 (50\%) of 22 programmes offering HBV testing, and enzyme immunoassay (EIA) by $4(20 \%)$ of 20 and 6 (27.3\%) of 22 programmes, respectively. Nucleic acid testing (NAT) for confirmation of viraemia was available in only $6(30 \%)$ of 20 programmes for HCV RNA (Hong Kong SAR/China, Mongolia, Thailand, Uganda and two programmes in Vietnam), and 4 programmes $(18.2 \%)$ of 22 for HBV DNA (Myanmar, Philippine, Uganda and one programe in Vietnam). EIA and NAT were more likely to be available in hospital-based programmes.

Although, the majority $(19,86.4 \%$ for HBV and 15, 75\% for HCV) of the programmes had a budget for testing, around a third of programmes required some patient selfpayment for testing, and for $18.2 \%$ of programmes, this was partly covered by private insurance. In the case of treatment, around a third of programmes provided funding for $\mathrm{HCV}$ and $\mathrm{HBV}$ treatment, and two thirds required patient self-payment.

\section{Further investigations, care and treatment following diagnosis}

Fifteen $(68.2 \%)$ of the programmes offered pre- and/or post-counselling, and 16 (72.7\%) offered some level of further evaluation and staging of liver disease using Fibroscan (9, 40.9\%), or APRI or FIB-4 scoring based on readily available and cheap laboratory tests, such as liver transaminases and platelet count and other measures $(7,31.8 \%)$. Among the programmes providing HBV testing, only 12 (54.5\%) offered HBV vaccination in those who tested negative.

Four and six programmes offered no access to treatment for $\mathrm{HBV}$ and $\mathrm{HCV}$, respectively, despite offering testing. Although 18 programmes indicated that HBV treatment was available in the country, in 9 programmes this was only for HIV-HBV co-infected persons through use of tenofovir-based antiretroviral regimens, or for those able to self-pay. Among the programmes which conducted 


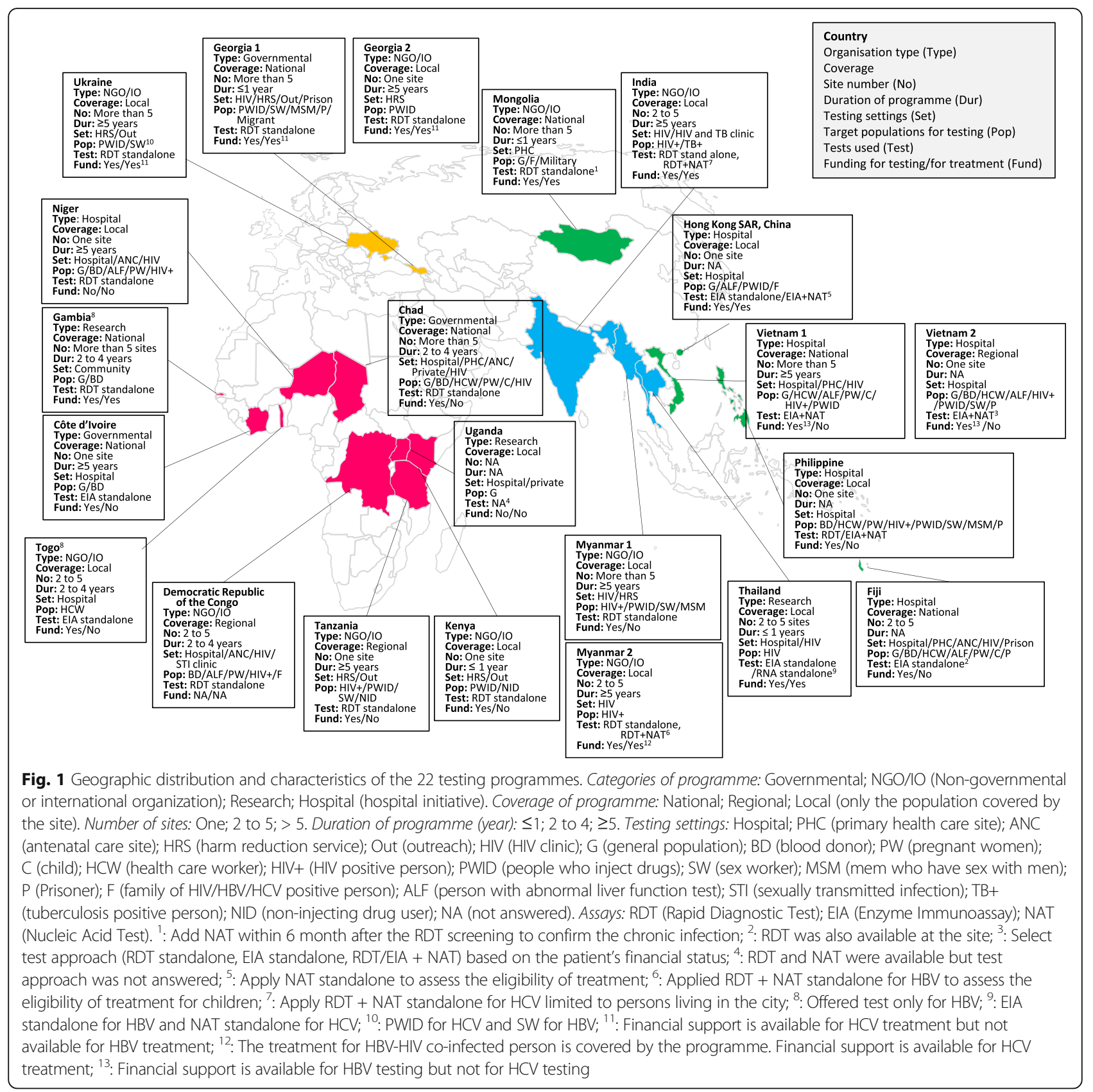

$\mathrm{HCV}$ testing, treatment was reported to be available in the country in $14(70 \%)$ of the 20 programmes, but only for those able to self-pay, or as part of pilot programmes or clinical trials. The exception was Georgia where $\mathrm{HCV}$ treatment was available through the national programme in those with advanced liver disease.

\section{Qualitative evaluation of perceived barriers and strategies to scale-up viral hepatitis testing}

Interviewees identified multiple different issues as barriers to testing, which were grouped into six key thematic categories: 1. Limited community awareness and education about viral hepatitis; 2. Lack of national guidance or policies and their implementation; 3. Funding - high costs of testing especially for NAT, and lack of dedicated funding for testing services; 4 . Laboratory issues - poor infrastructure, poor quality tests and lack of quality assurance; 5 . Service delivery and lack of trained healthcare workers to manage hepatitis; 6 . Lack of availability of HBV treatment for mono-infected patients and to new DAAs for $\mathrm{HCV}$ treatment. Table 3 summarises the issues most commonly raised within these six categories as well as specific proposed interventions to address these barriers. The four most critical interventions identified were: awareness 
Table 3 Key challenges in access to and scale-up of viral hepatitis testing and proposed interventions

\begin{tabular}{l} 
Challenges (number of \\
respondents highlighting issue) \\
\hline 1. Community awareness and \\
education \\
Lack of awareness among \\
community \\
- About disease and its \\
consequences (9) \\
- About value and availability of \\
testing services (1) \\
Health beliefs \\
- Delayed health-seeking \\
behaviour especially in \\
young men (2) \\
- Self-treatment and traditional \\
medicine (1) \\
- Fear of stigmatization (1)
\end{tabular}

\section{Service delivery}

Laboratory infrastructure

- Poor infrastructure and

lack of staff (10)

- Lack of access to NAT and

FibroScan (8)

- Concern about low quality

tests and lack of quality

assurance (4)

- Lack of supply management (3)

- Lack of assay for hepatitis delta virus (1)

- Dependence on blood sampling (1)

- Distance to testing services (mainly in urban settings) (1)

- Lack of laboratory network (1)

Poor linkage to hepatitis care

- Lack of linkage to care (7)

- Lack of access to harm reduction services (2)

3. Lack of access to treatment

- Unavailability of hepatitis

treatments (11)

- Lack of treatment for

children (1)

- Slow approval process for

new medicines (1)

4. Health care workers (HCW)/laboratory education

Lack of awareness among HCW

and service providers

- About disease and its

consequences (6)

- About value and availability

of testing services (3)

- Lack of physicians who

are able to treat hepatitis (especially in children) (2)

Lack of training

- For HCW, laboratory

technicians and

physicians (6)

5. National guidance and policies

- Lack of national guidance (6)
Proposed interventions

(number of respondents

highlighting issue)

\section{Community awareness and} education

- Increase awareness (11)

- Increase implementation of HBV vaccination (2)

\section{Service delivery}

- Expand access to assays and technologies: eg. DBS, oral test, point of care test, self-testing, GeneXpert and Fibroscan (12)

- Establish good quality assurance on laboratory tests (6)

- Decentralization of testing sites (3)

- Establishment of referral pathway and expand laboratory networks, to include central/private laboratories and existing HIV testing infrastructure and existing HIV structure (3)

- Offer integrated testing for multiple infections (for HCV, HBV, HIV) (2)

- Expand work with key populations (1)

- Prioritize testing in health care workers (1)

3. Lack of access to treatment - Expand treatment availability and access to cheap generic medicine (7)

\section{Health care workers (HCW)/} laboratory education

- Training/increase technical capacity of care teams in area of hepatitis (10)

- Need more staff (1)

- Establish a degree in hepatitis research (1)

5. National guidance and policies - Development of national guidelines/strategy (7)
Table 3 Key challenges in access to and scale-up of viral hepatitis testing and proposed interventions (Continued)

\begin{tabular}{|c|c|}
\hline $\begin{array}{l}\text { Challenges (number of } \\
\text { respondents highlighting issue) }\end{array}$ & $\begin{array}{l}\text { Proposed interventions } \\
\text { (number of respondents } \\
\text { highlighting issue) }\end{array}$ \\
\hline $\begin{array}{l}\text { - Policies not implemented (2) } \\
\text { - No epidemiological data on } \\
\text { viral hepatitis (2) } \\
\text { - Policies are discriminating/ } \\
\text { stigmatizing (1) }\end{array}$ & $\begin{array}{l}\text { - Advocacy with policy makers (4) } \\
\text { - Need surveillance data to identify } \\
\text { settings and populations with high } \\
\text { burden (3) } \\
\text { - Development of policy on PMTCT } \\
\text { for viral hepatitis (1) }\end{array}$ \\
\hline $\begin{array}{l}\text { 6. Funding } \\
\text { - Lack of sustained } \\
\text { funding commitment (9) } \\
\text { - High costs of testing and } \\
\text { additional assays to determine } \\
\text { treatment eligibility (3) }\end{array}$ & $\begin{array}{l}\text { 6. Funding } \\
\text { - Development of funding strategy } \\
\text { for testing and treatment (4) } \\
\text { - Costing assessment across cascade } \\
\text { of care (1) }\end{array}$ \\
\hline
\end{tabular}

$H C W$ health care worker, NAT nucleic acid testing, PMTCT prevent mother to child transmission, DBS dried blood spot. Issues identified by more than five respondants are presented in bold

raising within the community; expanded access to assays, including point-of-care tests; access to low cost generic drugs; training and capacity building of laboratory staff and healthcare workers; and development of national guidelines.

We also sought perspectives from interviewees on the ethics and rationale of testing by programmes where treatment was not available, given that there is still very limited access to $\mathrm{HBV}$ treatment for $\mathrm{HBV}$ mono-infected persons, and self-payment is currently required to access DAA $\mathrm{HCV}$ treatment for the majority of programmes. Key reasons given by respondents from 12 programmes for testing in the absence of treatment were to provide: (i) a platform for health education and health promotion; (ii) counselling of high risk anti-HCV negative persons on how to remain negative, or $\mathrm{HBV}$ vaccination of those who are HBV non-immune; and counselling of $\mathrm{HCV}$ and HBV positive persons and family members how to prevent transmission, and reduce disease progression, such as through alcohol cessation. Testing among health care workers for viral hepatitis was also identified as another situation where testing would be appropriate to enable vaccination of non-immune $\mathrm{HCW}$ even in the absence of treatment and adoption of measures to minimize risk of transmission from infected HCW to patients. Finally, testing was seen as an essential part of surveillance to gather national epidemiological data on $\mathrm{HCV}$ and $\mathrm{HBV}$ infection to inform advocacy for increasing treatment access and to raise awareness among the community.

\section{Discussion}

There is still limited published experience of viral hepatitis testing and treatment in low- and middle-income countries to inform development of future programmes. 
This survey of 22 different hepatitis testing programmes in 19 predominantly low- and middle-income countries in Africa, Asia and Eastern Europe (of which 4 were from upper-middle income countries) representing a wide range of different $\mathrm{HBV}$ and $\mathrm{HCV}$ prevalence and epidemic patterns provides several valuable insights into current practices and future priorities in the delivery of hepatitis testing.

Overall, half of the programmes were being implemented by NGOs or IOs, and about half of them were only being implemented at a few sites, and so are not representative of national testing policies and approaches. The majority of testing programmes involved targeted testing of high-risk populations such as PWID, men who have sex with men (MSM), sex workers and prisoners, but also pregnant women and health care workers, alone or in combination with some general population testing approaches. NGO/IO supported programmes had a greater emphasis on testing of key and marginalised populations with the few government programmes supporting a general population testing approach. The majority of testing was undertaken in hospital-based settings, and in HIV, Tuberculosis (TB) and sexually transmitted infection (STI) clinics, and antenatal clinics. There was limited community-based or outreach testing. Of note, around half of the countries included in the survey have existing national policies on routine HBV screening for all pregnant women, and were Fiji, Georgia, Hong Kong SAR/China, India, Kenya, Myanmar, Philippine, Thailand and Ukraine [71-88].

There were several other common features to these testing programmes: First, two-thirds of the programmes were using a single RDT serological test for HBV and HCV. Second, 70\% of the testing programmes were integrating viral hepatitis testing with existing clinics and services in HIV, TB and STI clinics as well as harm reduction services - alongside testing for HIV, TB and syphilis, as viral hepatitis is also prevalent in these populations. Third, in the programmes surveyed viral hepatitis testing was still provider-initiated by a physician in the majority of testing programmes, although this largely reflects practices in the predominantly facility-based programmes included in the survey. Fourth, staging of liver disease to assess eligibility for treatment was being undertaken by $73 \%$ of programmes, about a half of them with use of Fibroscan rather than the lower cost and more available APRI score. NAT testing to confirm the presence of viraemia and treatment eligibility was only performed by 6 of the HCV programmes and 4 of the HBV programmes. Fifth, it was of concern that $18 \%$ of programmes were not able to offer treatment for HBV mono-infection despite the wide availability of low cost generic tenofovir, and around a quarter were not providing HCV treatment. In addition, around a third of programmes were not routinely providing $\mathrm{HBV}$ vaccination, a low cost and highly effective preventative measure. Finally, although the testing costs were wholly or partly supported by the programme in more than $80 \%$ of the programmes, funding was covered by additional patient selfpayment or private insurance in around a third. Treatment cost were covered by programmes in a third of cases.

The survey identified key barriers to testing services across different aspects of the health system but also some key strategies to address these challenges. Key strategies to facilitate access to testing identified from the survey were: awareness raising about viral hepatitis among the general population; decentralization of hepatitis testing with quality assurance on laboratory tests, and expanding access to technologies such as point of care NAT such as GeneXpert, dried blood spots sampling, use of oral RDT and self-testing; improving the training and capacity of staff in management of hepatitis; and incorporation of hepatitis testing and treatment into national health reimbursement programmes. Other diagnostic innovations to promote testing include multianalyte testing, multiplex analysis or multi platforms for testing combined with syphilis [3, 89, 90]. Dried blood spot sampling may enhance access to both serological (using laboratory based EIA assays) and virological (using nucleic acid tests) testing [91]. However, at present, none of the manufacturers of commercial assays have validated their use with DBS samples or developed standard operating procedures, and nor is there any regulatory approval for their use from stringent regulatory authorities, such as WHO. The limited availability of low cost generic DAA treatments for $\mathrm{HCV}$ infection and tenofovir therapy for HBV mono-infected persons in many programmes was also identified as a key impediment to testing. Of note, 11 programmes highlighted the other benefits of testing in the absence of current access to treatment. These include opportunities to introduce measures and counselling to reduce transmission to family members and other close contacts including hepatitis B vaccination, and to counsel infected persons about measures to reduce disease progression of liver disease.

How well do our findings relate to existing reports on programmatic experience in viral hepatitis testing? We identified 49 published reports from different viral hepatitis testing programmes based on a PubMED search of existing relevant literatures on hepatitis $\mathrm{B}$ or $\mathrm{C}$ testing practices published since 2007 [7-55]. The majority of these $(88 \%)$ were from high-income countries, mainly the United States and Western Europe, with only 6 from 
LMICs. These reports described testing programmes in a range of populations including: 13 of $\mathrm{HCV}$ birth-cohort testing in the context of the United States national recommendation to screen all adults living in the United States born between 1945 and 1965 at least once $[8,16,19,22-25,38,42,45,47,51,53] ; 10$ of $\mathrm{HCV}$ and one of both HBV and HCV in people who use drugs or harm reduction settings $[10,12,20,21,32,34$, 35, 39-41, 51]; 4 of $\mathrm{HCV}$ in prisons [7, 15, 17, 54]; 3 of HBV testing in pregnant women $[29,46,52]$; and one of $\mathrm{HBV}$ and one of HCV in migrants [14, 43]. Of note, most of the programmes described were also community based or implemented in primary health care or prevention services. Although, descriptions of testing models and an evaluation of impact on cascade of care were provided in most of the reports, there was limited critical evaluation of programmatic lessons learnt.

In contrast, our survey was based on a broad range of facility and community based testing programmes from mainly LMICs with a focus on experiences with current testing practices, and common barriers. There were several key limitations to this survey. First, it was based on an opportunistic sample of 22 testing programmes that did not include any from Latin America or the Caribbean. Second, included programmes are not representative of national testing policies and approaches, as half of the programmes were being implemented by NGOs or IOs, and about half of them were only being implemented at a few sites. Third, the majority of programmes were also based in health facilities and there were few community based or outreach initiatives, which are likely to have different lab and service delivery approaches and unique challenges. There was also considerable variability in the way programmes were organised, especially between $\mathrm{NGO} / \mathrm{IO}$ and governmental programmes, and so it was difficult to standardise reporting and data collection of their experiences, and to draw any inferences about programmatic effectiveness.

\section{Conclusions}

What were the implications of our findings for both the formulation of recommendations in the WHO testing guidelines [4] and for future strategies to promote scale-up of viral hepatitis testing globally? The survey demonstrates that progress has been made in scale-up of hepatitis testing under the auspices of government and non-governmental initiatives, building on existing opportunities for testing through other services and on laboratory infrastructure. In spite of the many barriers highlighted, it also shows the feasibility of implementing $\mathrm{HBV}$ and $\mathrm{HCV}$ testing programmes across a wide range of LMICs. In particular, targeted testing is being effectively implemented among various higher risk groups, and RDTs have been widely adopted. However, there remains limited access to NAT for assessment of viraemia, and requirement for patient co-payment for testing and treatment remains a significant barrier.

These issues of feasibility and challenges encountered were considered in the formulation of recommendations on who to test and how to test in the 2017 WHO guidelines on testing for hepatitis B and $C$ [4], with a promotion of the use of quality assured RDTs to promote access, strategies to promote linkage to care and treatment, use of simple low-cost non-invasive tests (NITs) such as APRI score for staging of liver disease, and universal adoption of targeted or focussed testing of specific populations most affected by HBV or HCV infection (i.e. who are either part of a population with higher seroprevalence or who have a history of exposure to or high-risk behaviours for HBV or HCV infection). These include HIV infected persons, PWID, prisoners, sexual partners and family members, including children of those affected by hepatitis B, pregnant women and health care workers. General population testing was recommended in high prevalence countries (above 5\%) using existing testing infrastructure and approaches.

In terms of future policy, there is scope for increasing community-based testing and involving nonhealth workers with task-shifting to promote testing as achieved with HIV [92], and in access to point of care NAT technologies as well as dried blood spots sampling to improve access to virological testing. As countries progressively embrace universal health coverage, the current barrier to testing of costly selfpayment of diagnostics can also be addressed. Finally, there is a need for more systematic reporting of experience with hepatitis testing and treatment programmes in LMICs. This will be further informed by a portfolio of important implementation science and demonstration projects supported by UNITAID and other organisations examining the impact of simplified and decentralised hepatitis $C$ testing and treatment programmes.

\section{Additional file}

Additional file 1: Questionnaire sheets for feasibility survey. (PDF $176 \mathrm{~kb}$ )

\section{Abbreviations}

DAA: Direct acting anti-viral; ElA: Enzyme immunoassay; GHP: Global Hepatitis Programme; HBV: Hepatitis B virus; HCC: Hepatocellular carcinoma; HCV: Hepatitis C virus; HIV: Human immunedeficiency virus; IO: International organizations; LMICs: Low- and middle-income countries; MdM: Médecins du Monde; MSF: Médecins sans Frontières; MSM: Men who have sex with men; NAT: Nucleic acid testing; NGO: Non-governmental organizations; PWID: People who inject drugs; RDT: Rapid diagnostic tests 


\section{Acknowledgements}

We would like to acknowledge to all experts kindly participated to this feasibility survey: Albert Minga (National Program Ivory Coast, Abidjan, Côte d'Ivoire), Ali Mahamat Moussa (Esther/Expertise France, Ndjamena, Chad), Boubakar Madougou (Esther/Expertise France, Niamey, Niger), George Macharia Wambugu (Médicins du Monde, Nairobi, Kenya), Henry Ly Chan (The Chinese University of Hong Kong, Hong Kong, China), Ina Inaridze (Médicins du Monde, Tbilisi, Georgia), Isabelle Andrieux-Meyer (Médecins Sans Frontières, Geneva, Switherland), Janus Ong (Philippine General Hospital, Manila, Philippines), Joseph Larmarange (Agence nationale de recherche sur le sida et les hépatites virales, Côte d'Ivoire), Kizys Herbocszek (Médecins Sans Frontières, Manipur, India), Mai Ling Perman (Colonial War Memorial Hospital, Suva, Fiji), Maud Lemoine (Imperial College, London, United Kingdom), Naranbaatar Dashdorj (Onom Foundation, Ulan Bator, Mongolia), Nguyen Vu Trung (National Hospital for Tropical Disease, Hanoi, Vietnam), Paata Sabelashvili (National Member of HCV elimination Comission, Georgia), Pham Van Anh (Haiphong medical and pharmaceutical university, Haiphong, Vietnam), Ponsiano Ocama (Makerere University, Kampla, Uganda), Nicolas Durier (Treat Asia/amfAR, Bangkok, Thailand), Tatiana Barnard (Alliance, Kiev, Ukraine), Than Min Htike (Médicins du Monde, Yangoon, Myanmar), Xavier Assamagan (Esther/Expertise France, Lome, Togo) and Zin Mar Han (Médicins du Monde, Dar es Salam, Tanzania).

We would like to extend our gratitude to the staff of the Global Hepatitis Programme, WHO for their excellent support: Hande Harmanci, Judith Van Holten, Yvan Hutin, and Stefan Wiktor.

\section{Funding}

Publication of this article was funded by the World Health Organization.

\section{Availability of data and materials}

The datasets used and/or analysed during the current study are available from the corresponding author on reasonable request.

\section{About this supplement}

This article has been published as part of BMC Infectious Diseases Volume 17 Supplement 1, 2017: Testing for chronic hepatitis B and C - a global perspective. The full contents of the supplement are available online at https://bmcinfectdis.biomedcentral.com/articles/supplements/volume-17supplement-1.

\section{Authors' contributions}

$\mathrm{PE}$ and $\mathrm{SH}$ designed the study with input from $\mathrm{El}$ and TR in developing questionnaire. Al, NL, JB, SL, RC, NW, SH and PE conducted interviews. Al was responsible for overall data synthesis with input from JB and drafted the manuscript. JB, NL and PE revised the manuscript critically. All authors read and approved the final manuscript.

\section{Ethics approval and consent to participate}

Not applicable.

\section{Consent for publication}

Not applicable.

\section{Competing interests}

The authors declare that they have no competing interests.

\section{Publisher's Note}

Springer Nature remains neutral with regard to jurisdictional claims in published maps and institutional affiliations

\section{Author details}

'Global Hepatitis Programme, World Health Organization, 20 Avenue Appia, 1211, 27 Geneva, Switzerland. ' Médecins du Monde, 62 rue Marcadet, 75018 Paris, France. ${ }^{3}$ World Health Organization, Regional Office of the Western Pacific, United Nations Avenue, 1000 Manila, Philippines. ${ }^{4}$ Foundation for Innovative New Diagnostics, Campus Biotech, Building B2, Level 0, 9 Chemin des Mines, 1202 Geneva, Switzerland.
Published: 1 November 2017

\section{References}

1. World Health Organization. Global Hepatitis Report 2017. 2017: Geneva. http://apps.who.int/iris/bitstream/10665/255016/1/9789241565455-eng. pdf?ua=1. Accessed 25 Apr 2017

2. Stanaway JD, Flaxman AD, Naghavi M, Fitzmaurice C, Vos T, Abubakar I et al. The global burden of viral hepatitis from 1990 to 2013: findings from the global burden of disease study 2013. Lancet. 2016;388(10049):1081-8.

3. Easterbrook PJ, Roberts T, Sands A, Peeling R. Diagnosis of viral hepatitis. Curr Opin HIV AIDS. 2017:12(3):302-14.

4. World Health Organization. Guidelines on hepatitis B and C testing. Geneva: 2017. http://apps.who.int/iris/bitstream/10665/254621/1/9789241549981eng.pdf?ua=1. Accessed 25 Apr 2017

5. Guyatt G, Oxman AD, Akl EA, Kunz R, Vist G, Brozek J, et al. GRADE guidelines: 1. Introduction - GRADE evidence profiles and summary of findings tables. J Clin Epidemiol. 2011;64(4):383-94.

6. World Health Organization. Handbook for guideline development. Geneva: 2014. http://apps.who.int/medicinedocs/documents/s22083en/s22083en.pdf. Accessed 25 Apr 2017.

7. Akiyama MJ, Kaba F, Rosner Z, Alper H, Kopolow A, Litwin AH, et al. Correlates of hepatitis $C$ virus infection in the targeted testing program of the new York City jail system. Public Health Rep. 2017;132(1):41-7.

8. Allison WE, Chiang W, Rubin A, Oshva L, Carmody E. Knowledge about hepatitis C virus infection and acceptability of testing in the 1945-1965 birth cohort (baby boomers) presenting to a large urban emergency department: a pilot study. J Emerg Med. 2016;50(6):825-31.e2.

9. Alswaidi FM, O'Brien SJ. Is there a need to include HIV, HBV and HCV viruses in the Saudi premarital screening program on the basis of their prevalence and transmission risk factors? J Epidemiol Community Health. 2010;64(11):989-97.

10. Anderson EM, Mandeville RP, Hutchinson SJ, Cameron SO, Mills PR, Fox R, et al. Evaluation of a general practice based hepatitis $C$ virus screening intervention. Scott Med J. 2009;54(3):3-7.

11. Anderson ES, Pfeil SK, Alter HJ, White DA. Patient understanding of HIV and hepatitis $C$ testing in an emergency department with an integrated program. J Int Assoc Provid AIDS Care. 2016;15(3):184-8.

12. Arain A, De Sousa J, Corten K, Verrando R, Thijs H, Mathei C, et al. Pilot study: combining formal and peer education with FibroScan to increase HCV screening and treatment in persons who use drugs. J Subst Abus Treat. 2016:67:44-9.

13. Barragan NC, Chang M, Felderman J, Readhead H, Kuo T. A case study of a hepatitis B screening and blood pressure assesment program in Los Angeles County, 2012-2013. Prev Chronic Dis. 2015;12:E19.

14. Batash S, Khaykis I, Raicht RF, Bini EJ. High prevalence of hepatitis C virus infection among immigrants from the former Soviet Union in the New York City metropolitan area: results of a community-based screening program. Am J Gastroenterol. 2008:103(4):922-7.

15. Beckwith CG, Kurth AE, Bazerman LB, Patry EJ, Cates A, Tran L, et al. A pilot study of rapid hepatitis $C$ virus testing in the Rhode island department of corrections. J Public Health (Oxf). 2016;38(1):130-7.

16. Brady JE, Liffmann DK, Yartel A, Kil N, Federman AD, Kannry J, et al. Uptake of hepatitis $C$ screening, characteristics of patients tested, and intervention costs in the BEST-C study. Hepatology. 2017:65(1):44-53.

17. Cocoros N, Nettle E, Church D, Bourassa L, Sherwin V, Cranston K, et al. Screening for hepatitis $C$ as a prevention enhancement (SHAPE) for HIV: an integration pilot initiative in a Massachusetts County correctional facility. Public Health Rep. 2014;129(Suppl 1):5-11.

18. Defossez G, Verneau A, Ingrand I, Silvain C, Ingrand P, Beauchant M, et al. Evaluation of the French national plan to promote screening and early management of viral hepatitis C, between 1997 and 2003: a comparative cross-sectional study in Poitou-Charentes region. Eur J Gastroenterol Hepatol. 2008;20(5):367-72.

19. Federman AD, Kil N, Kannry J, Andreopolous E, Toribio W, Lyons J et al. An Electronic Health Record-based Intervention to Promote Hepatitis C Virus Testing Among Adults Born Between 1945 and 1965: A Cluster-randomized Trial. Med Care. 2017:55(6):590-7.

20. Fernàndez-López L, Folch C, Majó X, Gasulla L, Casabona J. Implementation of rapid HIV and HCV testing within harm reduction programmes for people who inject drugs: a pilot study. AIDS Care. 2016;28(6):712-6. 
21. Frimpong JA, D'Aunno T. Hepatitis $C$ testing in substance use disorder treatment: the role of program managers in adoption of testing services. Subst Abuse Treat Prev Policy. 2016;11:13.

22. García-Alonso FJ, Bonillo-Cambrodón D, Bermejo A, García-Martínez J, Hernández-Tejero M, Valer López Fando P, et al. Acceptance, yield and feasibility of attaching HCV birth cohort screening to colorectal cancer screening in Spain. Dig Liver Dis. 2016;48(10):1237-42.

23. Groom H, Dieperink E, Nelson DB, Garrard J, Johnson JR, Ewing SL, et al. Outcomes of a hepatitis $C$ screening program at a large urban VA medical center. J Clin Gastroenterol. 2008;42(1):97-106.

24. Hirsch AA, Lawrence RH, Kern E, Falck-Ytter Y, Shumaker DT, Watts B. Implementation and evaluation of a multicomponent quality improvement intervention to improve efficiency of hepatitis $C$ screening and diagnosis. Jt Comm J Qual Patient Saf. 2014;40(8):351-7.

25. Jorgensen C, Carnes CA, Downs A. "Know more hepatitis:" CDC's National Education Campaign to increase hepatitis $C$ testing among people born between 1945 and 1965. Public Health Rep. 2016; 131(Suppl 2):29-34.

26. Juon HS, Lee S, Strong C, Rimal R, Kirk GD, Bowie J. Effect of a liver cancer education program on hepatitis B screening among Asian Americans in the Baltimore-Washington metropolitan area, 2009-2010. Prev Chronic Dis. 2014;11:130258

27. Kania D, Sangaré L, Sakandé J, Koanda A, Nébié YK, Zerbo O, et al. A new strategy to improve the cost-effectiveness of human immunodeficiency virus, hepatitis B virus, hepatitis C virus, and syphilis testing of blood donations in sub-Saharan Africa: a pilot study in Burkina Faso. Transfusion. 2009;49(10):2237-40

28. Kapeluto J, Kadatz M, Wormsbecker A, Sidhu K, Yoshida EM. Screening, detecting and enhancing the yield of previously undiagnosed hepatitis $B$ and $C$ in patients with acute medical admissions to hospital: a pilot project undertaken at the Vancouver general hospital. Can J Gastroenterol Hepatol. 2014;28(6):315-8

29. Keel P, Edwards G, Flood J, Nixon G, Beebeejaun K, Shute J, et al. Assessing the impact of a nurse-delivered home dried blood spot service on uptake of testing for household contacts of hepatitis B-infected pregnant women across two London trusts. Epidemiol Infect. 2016:144(10):2087-97.

30. Kierzek G, Aslangul E, Le Guerroué G, Le Jeunne C, Pourriat JL. Feasibility of a nontargeted active opt-in HIV, HBV, and HCV testing in an academic emergency department. Eur J Emerg Med. 2009;16(2):111-2.

31. Lemoine M, Shimakawa Y, Njie R, Taal M, Ndow G, Chemin I. Acceptability and feasibility of a screen-and-treat programme for hepatitis $B$ virus infection in the Gambia: the prevention of liver fibrosis and cancer in Africa (PROLIFICA) study. Lancet Glob Health. 2016;4(8):e559-67.

32. Mclnnes DK, Hyun JK, Trafton JA, Asch SM, Gifford AL. Program characteristics associated with testing for HIV and hepatitis $C$ in veterans substance use disorder clinics. Psychiatr Serv. 2010;61(1):90-4.

33. Mclver R, Dyda A, Knight V, Guy R, McNulty A. Hepatitis B screening and vaccination: how does a sexual health service measure up? Sex Health. 2015;12(5):458-9.

34. McLeod A, Weir A, Aitken C, Gunson R, Templeton K, Molyneaux P, et al. Rise in testing and diagnosis associated with Scotland's action plan on hepatitis $C$ and introduction of dried blood spot testing. J Epidemiol Community Health. 2014;68(12):1182-8.

35. Merchant RC, Baird JR, Liu T, Taylor LE, Montague BT, Nirenberg TD. Brief intervention to increase emergency department uptake of combined rapid human immunodeficiency virus and hepatitis $C$ screening among a drug misusing population. Acad Emerg Med. 2014;21(7):752-67.

36. Moss T, Martin CW, Klausner JD, Brown BJ. Integration of screening for syphilis, hepatitis $C$, and other sexually transmitted infections with HIV testing in a community-based HIV prevention program in Miami, Florida. LGBT Health. 2014;1(2):82-5.

37. O'Connell S, Lillis D, Cotter A, O'Dea S, Tuite H, Fleming C, et al. Opt-out panel testing for HIV, hepatitis $B$ and hepatitis $C$ in an urban emergency department: a pilot study. PLoS One. 2016;11(3):e0150546.

38. Reilley B, Leston J, Hariri S, Neel L, Rudd M, Galope M, et al. Birth cohort testing for hepatitis C virus - Indian Health Service 2012-2015. MMWR Morb Mortal Wkly Rep. 2016;65(18):467-9.

39. Reynolds GL, Fisher DG, Napper LE, Marsh KA, Willey C, Brooks R. Results from a multiple morbidities testing program offering rapid HIV testing bundled with hepatitis and sexually transmitted infection testing. Public Health Rep. 2008;123(Suppl 3):63-9.
40. Roux P, Rojas Castro D, Ndiaye K, Debrus M, Protopopescu C, Le Gall JM, et al. Increased uptake of HCV testing through a community-based educational intervention in difficult-to-reach people who inject drugs: results from the ANRS-AERLI study. PLoS One. 2016;11(6):e0157062.

41. Seña AC, Willis SJ, Hilton A, Anderson A, Wohl DA, Hurt CB, et al. Efforts at the frontlines: implementing a hepatitis $C$ testing and linkageto-care program at the local public health level. Public Health Rep. 2016;131(Suppl 2):57-64.

42. Shahnazarian V, Karu E, Mehta P. Hepatitis C: improving the quality of screening in a community hospital by implementing an electronic medical record intervention. BMJ Qual Improv Rep. 2015;4(1). doi:10.1136/bmjquality. u208549.w3409. (eCollection 2015).

43. Shankar H, Blanas D, Bichoupan K, Ndiaye D, Carmody E, Martel-Laferriere V, et al. A novel collaborative community-based hepatitis B screening and linkage to care program for African immigrants. Clin Infect Dis. 2016; 62(Suppl 4):S289-97.

44. Sharifian A, Naderi N, Sanati A, Mohebi SR, Azimzadeh P, Golmohamadi A, et al. The early results of a new health care program implementation in HBV screening: an Iranian experience. Middle East J Dig Dis. 2015;7(4):226-32.

45. Sidlow $R$, Msaouel $P$. Improving hepatitis $C$ virus screening rates in primary care: a targeted intervention using the electronic health record. J Healthc Qual. 2015;37(5):319-23.

46. Smith A, Sabidó M, Camey E, Batres A, Casabona J. Lessons learned from integrating simultaneous triple point-of-care screening for syphilis, hepatitis $B$, and HIV in prenatal services through rural outreach teams in Guatemala. Int J Gynaecol Obstet. 2015;130(Suppl 1):S70-2.

47. Southern WN, Norton B, Steinman M, DeLuca J, Drainoni ML, Smith BD, et al. A birth-cohort testing intervention identified hepatitis $\mathrm{c}$ virus infection among patients with few identified risks: a cross-sectional study. BMC Infect Dis. 2015;15:553.

48. Southern WN, Drainoni ML, Smith BD, Koppelman E, McKee MD, Christiansen $\mathrm{CL}$, et al. Physician nonadherence with a hepatitis $\mathrm{C}$ screening program. Qual Manag Health Care. 2014;23(1):1-9.

49. Srisupanant $M$, Wiwanitkit $V$. Prevalence of hepatitis B seropositivity among Thai workers in screening program before going abroad. Ann Hepatol. 2008;7(4):389.

50. Trooskin SB, Poceta J, Towey CM, Yolken A, Rose JS, Luqman NL, et al. Results from a geographically focused, community-based HCV screening, linkage-to-care and patient navigation program. J Gen Intern Med. 2015;30(7):950-7.

51. White DA, Anderson ES, Pfeil SK, Trivedi TK, Alter HJ. Results of a rapid hepatitis $C$ virus screening and diagnostic testing program in an urban emergency department. Ann Emerg Med. 2016;67(1):119-28.

52. Xia J, Rutherford S, Ma Y, Wu L, Gao S, Chen T, et al. Obstacles to the coordination of delivering integrated prenatal HIV, syphilis and hepatitis B testing services in Guangdong: using a needs assessment approach. BMC Health Serv Res. 2015;15:117.

53. Younossi ZM, LaLuna LL, Santoro JJ, Mendes F, Araya V, Ravendhran N, et al. Implementation of baby boomer hepatitis $C$ screening and linking to care in gastroenterology practices: a multi-center pilot study. BMC Gastroenterol. 2016:16:45.

54. Zaller ND, Patry EJ, Bazerman LB, Noska A, Kuo I, Kurth A, et al. A pilot study of rapid hepatitis $C$ testing in probation and parole populations in Rhode Island. J Health Care Poor Underserved. 2016;27(2A):214-23.

55. Zuure FR, Heijman T, Urbanus AT, Prins M, Kok G, Davidovich U. Reasons for compliance or noncompliance with advice to test for hepatitis $C$ via an internet-mediated blood screening service: a qualitative study. BMC Public Health. 2011;11:293

56. Braun V, Clarke V. Using thematic analysis in psychology. Qual Res Psychol. 2006;3(2):77-101.

57. The World Bank. World Bank Country and Lending Groups. 2017. https://datahelpdesk.worldbank.org/knowledgebase/articles/906519. Accessed 25 Apr 2017.

58. Schweitzer A, Horn J, Mikolajczyk RT, Krause G, Ott JJ. Estimations of worldwide prevalence of chronic hepatitis B virus infection: a systematic review of data published between 1965 and 2013. Lancet. 2015:386(10003):1546-55.

59. Suesstrunk J, Djongali FB. Hepatitis B virus prevalence in rural areas in south-west Chad. Trop Dr. 2017:47(4):374-7.

60. Mboto Cl, Fielder M, Davies-Russell A, Jewell AP. Hepatitis C virus prevalence and serotypes associated with HIV in the Gambia. $\mathrm{Br} J$ Biomed Sci. 2010;67(3):140-4.

61. Wasitthankasem R, Posuwan N, Vichaiwattana P, Theamboonlers A Klinfueng S, Vuthitanachot $V$, et al. Decreasing hepatitis $C$ virus infection in 
Thailand in the past decade: evidence from the 2014 National Survey. PLoS One. 2016:11(2):e0149362.

62. Bessimbaye N, Moussa AM, Mbanga D, Tidjani A, Mahamat SO, Ngawara MN, et al. Seroprevalence of HBs Ag and of anti-HCV antibodies among HIV infected people in N'Djamena, Chad. Bull Soc Pathol Exot. 2014;107(5):327-31.

63. Ishizaki A, Tran VT, Nguyen $\mathrm{CH}$, Tanimoto T, Hoang HTT, Pham HV, et al. Discrepancies in prevalence trends for HIV, hepatitis B virus, and hepatitis $C$ virus in Haiphong, Vietnam from 2007 to 2012. PLoS One. 2017;12(6):e0179616

64. Harrison GL, Pryor J, Malani J, Supuri M, Masta A, Teriboriki B, et al. Infection frequency of hepatitis C virus and IL28B haplotypes in Papua New Guinea, Fiji, and Kiribati. PLoS One. 2013;8(8):e66749.

65. Khin M, Oo S-S, Oo KM, Shimono K, Koide N, Okada S. Prevalence and factors associated with hepatitis C virus infection among Myanmar blood donors. Acta Med Okayama. 2010;64(5):317-21.

66. Hope VD, Eramova I, Capurro D, Donoghoe MC. Prevalence and estimation of hepatitis B and C infections in the WHO European region: a review of data focusing on the countries outside the European Union and the European free trade association. Epidemiol Infect. 2014;142(2):270-86.

67. Iles JC, Abby Harrison GL, Lyons S, Djoko CF, Tamoufe U, Lebreton M, et al. Hepatitis C virus infections in the Democratic Republic of Congo exhibit a cohort effect. Infect Genet Evol. 2013;19:386-94.

68. Puri P, Anand AC, Saraswat VA, Acharya SK, Dhiman RK, Aggarwal R, et al. Consensus statement of HCV task force of the Indian National Association for study of the liver (INASL). Part I: status report of HCV infection in India. J Clin Exp Hepatol. 2014;4(2):106-16.

69. Mueller A, Stoetter L, Kalluvya S, Stich A, Majinge C, Weissbrich B, et al. Prevalence of hepatitis $B$ virus infection among health care workers in a tertiary hospital in Tanzania. BMC Infect Dis. 2015;15:386.

70. Lule G, Nyawira B. Guidelines for the Treatment of Chronic Hepatitis B and C Viral Infections in Kenya. Gastroenterology Society of Kenya; 2014. http://apps.who.int/ medicinedocs/documents/s21972en/s21972en.pdf. Accessed 28 June 2017.

71. Ministry of Health \& Social Welfare. The Gambia. Policy Guidelines for the Prevention of mother-to-Child HIV Transmission in the Gambia. 2010. http:// www.moh.gov.gm/sites/default/files/National\%20PMTCT\%20Guidelines\% 202010\%5B1\%5D.pdf. Accessed 28 June 2017.

72. Leroi C, Adam P, Khamduang W, Kawilapat S, Ngo-Giang-Huong N, Ongwandee $S$, et al. Prevalence of chronic hepatitis B virus infection in Thailand: a systematic review and meta-analysis. Int J Infect Dis. 2016;51:36-43.

73. Rouet F, Chaix ML, Inwoley A, Msellati P, Viho I, Combe P, et al. HBV and HCV prevalence and viraemia in HIV-positive and HIV-negative pregnant women in Abidjan, Côte d'Ivoire: the ANRS 1236 study. J Med Virol. 2004;74(1):34-40.

74. Tuinakelo LR, Tayler-Smith K, Khogali M, Marks GB. Prevalence of anaemia, syphilis and hepatitis B in pregnant women in Nausori, Fiji. Public Health Action. 2013;3(1):72-5.

75. Bayo P, Ochola E, Oleo C, Mwaka AD. High prevalence of hepatitis B virus infection among pregnant women attending antenatal care: a cross-sectional study in two hospitals in northern Uganda. BMJ Open. 2014;4(11):e005889.

76. Manyahi J, Msigwa Y, Mhimbira F, Majigo M. High sero-prevalence of hepatitis $B$ virus and human immunodeficiency virus infections among pregnant women attending antenatal clinic at Temeke municipal health facilities, Dar es salaam, Tanzania: a cross sectional study. BMC Pregnancy Childbirth. 2017:17(1):109.

77. Sibia P, Mohi MK, Kumar A. Seroprevalence of hepatitis B infection among pregnant women in one of the institute of northern India. J Clin Diagn Res. 2016;10(8):QC08-9.

78. World Health Organization. Global policy report on the prevention and control of viral hepatitis in WHO Member States. 2013: Geneva. http://apps.who.int/iris/ bitstream/10665/85397/1/9789241564632_eng.pdf. Accessed 28 June 2017.

79. Kravchuk I, Chumak NF, Schade RR, Hepburn IS. Hepatitis B in pregnancy in Ukraine: wasted chance. J Hepatol. 2015;62(suppl 2):S829-30.

80. Kabinda JM, Akilamalli TS, Miyanga AS, Donnen P, Michelle DW. Hepatitis-B, hepatitis-C and HIV in pregnant women in the Community in the Democratic Republic of Congo. World J AIDS. 2015;5(2):124-30.

81. IRIN. Focus on hepatitis. 2012. http://www.irinnews.org/news/2012/12/13/ focus-hepatitis. Accessed 28 June 2017.

82. Lavado R, Lagrada L, Ulep V, Tan L. Who provides good quality prenatal care in the Philippines? Philippine Institute for Development Studies; 2010. https://dirp4.pids.gov.ph/ris/dps/pidsdps1018.pdf. Accessed 28 June 2017.

83. Mamadou S, Ide M, Maazou A, Aoula B, Labo S, Bozari M. HIV infection and hepatitis B seroprevalence among antenatal clinic attendees in Niger, West
Africa. HIV/AIDS - Research and Palliative Care. 2012;4:1-4. https://pdfs. semanticscholar.org/6d3d/5b4e3f2885f2c8ca6ca2224919320cc4e8b6.pdf. Accessed 28 June 2017.

84. Mina M. Hepatitis B in Vietnam - A Crisis Waiting to Happen. Univ Tor Med J. 2013;90(3):110-3.

85. National Committee on HIV/AIDS. Mongolia. Mongolian National Strategic Plan on HIV, AIDS and STIs. 2010-2015. 2010. http://www. nationalplanningcycles.org/sites/default/files/planning_cycle_repository/ mongolia/hiv_plan_mongolia.pdf. Accessed 28 June 2017.

86. Ministry of Public Health and Sanitation and Ministry of Medical Services. Republic of Kenya. National guidelines for quality obstetrics and perinatal care. 2013. https:/www.k4health.org/sites/default/files/National\%20Guidelines \%20for\%20Quality\%200bstetrics\%20and\%20Perinatal\%20Care.pdf. Accessed 28 June 2017.

87. United Nations General Assembly Special Session on HIV/AIDS. Monitoring the Declaration of Commitment on HIV/AIDS. Georgia. Country report. 2006. http://data.unaids.org/pub/report/2008/georgia_2008_country_progress_ report_en.pdf. Accessed 28 June 2017.

88. Hong Kong Special Administrative Region Government. Pregnancy. 2014. https:/www.gov.hk/en/residents/health/sexedu/pregnancy.htm. Accessed 28 June 2017.

89. Pai NP, Dhurat R, Potter M, Behlim T, Landry G, Vadnais C, et al. Will a quadruple multiplexed point-of-care screening strategy for HIV-related co-infections be feasible and impact detection of new co-infections in at-risk populations? Results from cross-sectional studies. BMJ Open. 2014;4(12):e005040

90. Engmann CM, Khan S, Moyer CA, Coffey PS, Bhutta ZA. Transformative innovations in reproductive, maternal, newborn, and child health over the next 20 years. PLoS Med. 2016;13(3):e1001969.

91. Lange B, Roberts T, Cohn J, Greenman J, Camp J, Ishizaki A, et al. Diagnostic accuracy of detection and quantification of HBV-DNA and HCV-RNA using dried blood spot (DBS) samples - a systematic review and meta-analysis. BMC Infect Dis. 2017;17(Suppl 1). doi:10.1186/s12879-017-2776-Z.

92. World Health Organization. Consolidated guidelines on HIV testing services. 2015: Geneva. http://apps.who.int/iris/bitstream/10665/179870/1/ 9789241508926_eng.pdf?ua=1\&ua=1. Accessed 28 June 2017.

\section{Submit your next manuscript to BioMed Central and we will help you at every step:}

- We accept pre-submission inquiries

- Our selector tool helps you to find the most relevant journal

- We provide round the clock customer support

- Convenient online submission

- Thorough peer review

- Inclusion in PubMed and all major indexing services

- Maximum visibility for your research

Submit your manuscript at www.biomedcentral.com/submit
) Biomed Central 